\title{
Causes of Accident at Construction Sites in Bangladesh
}

DOI 10.2478/otmcj-2019-0003

Received November 16, 2018; accepted March 02, 2019

Abstract: Bangladeshi construction industry suffers more safety issues than other developing countries in the world. Among many of these, accidents at the construction site go far beyond and shape a horrific figure of death every year. The aims of this study are to identify and prioritize the causes of accidents. This study also analyses and discusses causes of accident at the construction site in Bangladesh. A widespread literature review and open discussion took place to identify the causes and design the questionnaire. The questionnaire-based survey was used to elicit the attitude of four stakeholders such as workers, owners, consultants and contractors towards the causes of accident. Mean and relative importance index (RII) were used to determine the rank of causes, and Statistical Package for the Social Sciences (SPSS) 23 was used to perform the data validation test. This study identifies 77 causes under 14 major groups and ranked them based on the mean and RII. The top five major groups of causes are management-, consultant-, technology-, labour- and contractor-related causes. The top five causes are unawareness of safety-related issue, lack of personal protective equipment, lack of safety eliminating/avoiding design, unfit equipment, lack of knowledge and training on equipment. This study will help the project participants and authorities to know and understand the various characteristics and linkage of causes of construction accidents to improve the construction safety management. It contributes to the body of knowledge, as it reveals for the first time the causes of accidents in the Bangladeshi construction industry.

Keywords: construction accident, construction site, causes, Bangladesh, questionnaire survey

\footnotetext{
*Corresponding author: Shakil Ahmed, Department of Building Engineering and Construction Management, Khulna University of Engineering \& Technology, Khulna-9203, Khulna, Bangladesh E-mail: ashakilmondol@gmail.com
}

\section{Introduction}

Construction industry is one of the most hazardous industries because of its unique nature. The construction projects are experiencing so many risks, uncertainties and complexities due to frequently happening accidents in the construction projects (Sousa et al. 2014). Most of the developed countries are trying to reduce the horrific damage and losses from construction accidents by preventing, eliminating and bypassing the possible accidents in construction projects. However, the developing countries are the extreme victim of construction accidents because they have no strict regulation on the construction safety and both authorities and employees are not aware of the construction safety issue (Biswas et al. 2017). Bangladesh is one of the most accident-prone construction industries among all the developing countries of the world. The Bangladeshi construction industry experiences more death, injuries, physical damage of properties, risks and complexities than other countries of the world due to the horrific figure of the occurring accidents and their fatal rate (Islam et al. 2017). Accident is a very important issue because of construction industry profile in Bangladesh. The construction sector has been greatly contributing to the Bangladeshi economic bombing for the last several years, and it shared $7.6 \%$ national GDP of the national economy in 2017 (Ahmed et al. 2018a). Trading Economics (Economics 2018), a well-known economy analysis platform and economic statistics source, reported that "GDP from Construction in Bangladesh increased to 7359.50 BDT Million in 2018 from 6695.10 BDT Million in 2017. GDP from Construction in Bangladesh averaged 4732.10 BDT Million from 2006 until 2018, reaching an all-time high of 7359.50 BDT Million in 2018 and a record low of 2982.50 BDT Million in 2006". This indicates that a large portion of economy and employment is under this industry. About 3.6 million people involved in this industry and any adverse effect on this industry could be the reasons for the suffering of this large portion of Bangladeshi people (Hossain and Ahmed 2018). 
Every year, an average of 150 people die and thousands get injured due to accidents in the construction projects in Bangladesh (Ahmed et al. 2018c). In 2017, the Bangladeshi construction industry faced death of about 179 people due to accidents, and in 2016 and 2015, the figure of death was 145 and 172 people, respectively (Ahemd and Bashar 2018). This scenario of accident represents a vulnerable level of construction safety practicing in the Bangladeshi construction projects. High officials from Bangladesh Occupational Safety, Health and Environment Foundation (OSHE Bangladesh) Bangladesh said:

accident in construction project is the topmost serious issue for the Bangladeshi construction. It is considered as the main barrier of innovation and development of the construction industry in Bangladesh. It brings so many complexities in many ways. It is bad, it is really bad for the Bangladeshi construction industry. (Report 2017)

Construction accident is a potential source of many problems and complexities in construction projects. Failure of adoption and assurance of construction safety against accident in construction projects have affected the projects negatively. It is the main cause of project delay (Aziz and Abdel-Hakam 2016; Burr 2016) and affects the quality of construction works (Larsen et al. 2015; Rumane 2016; Zeng et al. 2015), decreases the labourer's productivity (Hiyassat et al. 2016; Sveikauskas et al. 2016), leads to cost overrun of the project (Jadhav et al. 2016; Shehu et al. 2014), arises dispute between stakeholders (Gunduz et al. 2016) and affects the psychology of workers negatively (Leung et al. 2015). It shows a clear picture that the Bangladeshi industry is not going with good condition due to many issues, but the prime one is accidents in construction projects. Experts said that in Bangladesh, 80\% construction projects experience injuries and death from accidents. The consequences of accidents go far beyond the particular construction project.

Today, it is a basic right of every worker to work in a safe and accident-free workplace. Other countries in the world have started to reduce the accident rate, and they have shown success in various ways of reducing or even eliminating accidents in construction projects by having strong safety policy and practice. Bangladesh has to work in this issue seriously to reduce the accident rate and improve the construction industry with modern technologies and strategies. Numerous examinations have demonstrated that a fairly large percentage of fatal accident in the construction project could have been eliminated, reduced, or avoided if straightforward safety systems were applied at the sites and the employees were trained and made aware of the safety hazards present in the particular site (Zhang et al.
2013). A comprehensive safety program has to be designed to prevent, monitor and control accidents at the construction projects. For this, it is necessary to find out the reasons behind a large number of accidents. If the causes behind accidents at construction sites come to light, it will be easier for the authorities to take effective necessary steps to improve the safety program by considering these causes and reduce the accident rate in Bangladesh. To assist the authorities and improve the safety performance, the main purpose of this study is to investigate, identify and analyze the causes of accidents at construction sites in Bangladesh. This study may help the authorities and project executives to know and understand about the safety level and performance gaps at construction sites in Bangladesh. It could help authorities to find out the gaps in the existing safety management system and redesign it in the most effective way to reduce the accident rate. In addition, it will offer some suggestions that can play a vital role to decrease the accident rate, improve the safety performance and assist the stakeholders to complete construction project successfully without any accident.

\section{Current status of construction safety in Bangladesh}

The government enacted the following act/code at the national level to ensure health and safety of workers in the construction sector:

- Bangladesh Labour Act 2006 (BLA 2006)

- Bangladesh National Building Code 2006 (BNBC 2006)

The Bangladesh Labour Act 2006 (BLA 2006) includes all types of labourers who are involved in any type of work that is related to the GDP of the country. BLA is a common safety policy for all industries in Bangladesh. It does not cover all the safety issues of the construction projects (Hossain and Ahmed 2018). On the contrary, BNBC 2006 specifically deals with the labour safety of the building construction sector. However, this code is also not enough for construction safety management and is not compatible with OSHA regulations (Star 2017). Construction safety practice in Bangladesh is at very poor and concerning level. The existing culture is not favourable to the workers and site staffs for practicing safety rules and measures, and they also do not get any training on construction safety. Islam et al. (2015) stated that construction safety is absent or overlooked in most of the construction contracts in Bangladesh.

It can be seen from Figure 1 that a large portion of construction workers is not practicing safety regulations. 
There are many safety measures in BNBC and BLA that are not practiced by all most all workers $(100 \%)$ in Figure 1. However, a small number of workers practice safety regulation with a low scale but not appropriate as stated in regulations (Hossain and Ahmed 2018). This poor safety culture is the primary cause of the high rate of the construction accident. Figure 2 shows the fatal statistics due to the construction accidents from 2006 to 2017. The highest numbers of death occurred in 2011 with 183 people, followed by 2017 with 179 people and 2012 and 2013 with 175 people. It is clear that the fatal rate is increasing day by day since 2006. This figure states how important is to find out the causes of accidents in Bangladesh.

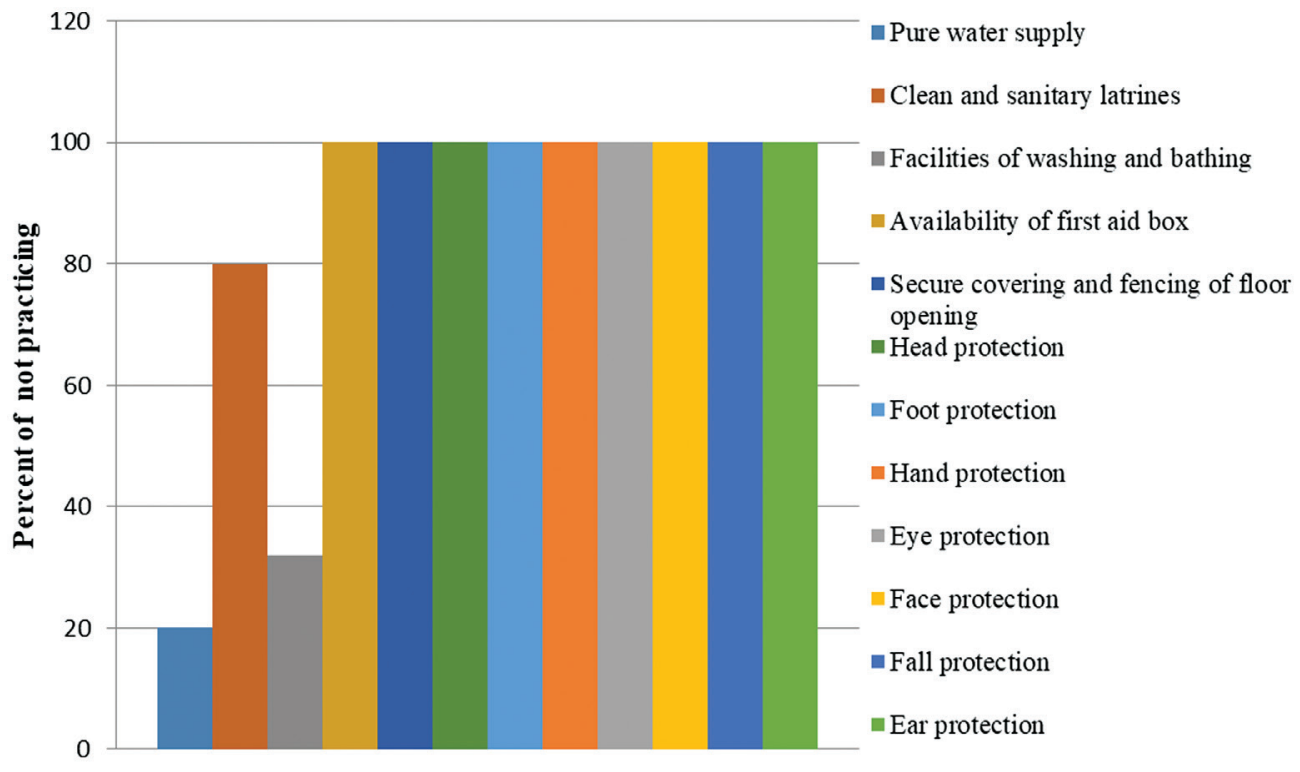

Type of protection and other facilities stated in BLA and BNBC-2006

Fig. 1: Current safety status in construction sites at Bangladesh (Hossain and Ahmed 2018).

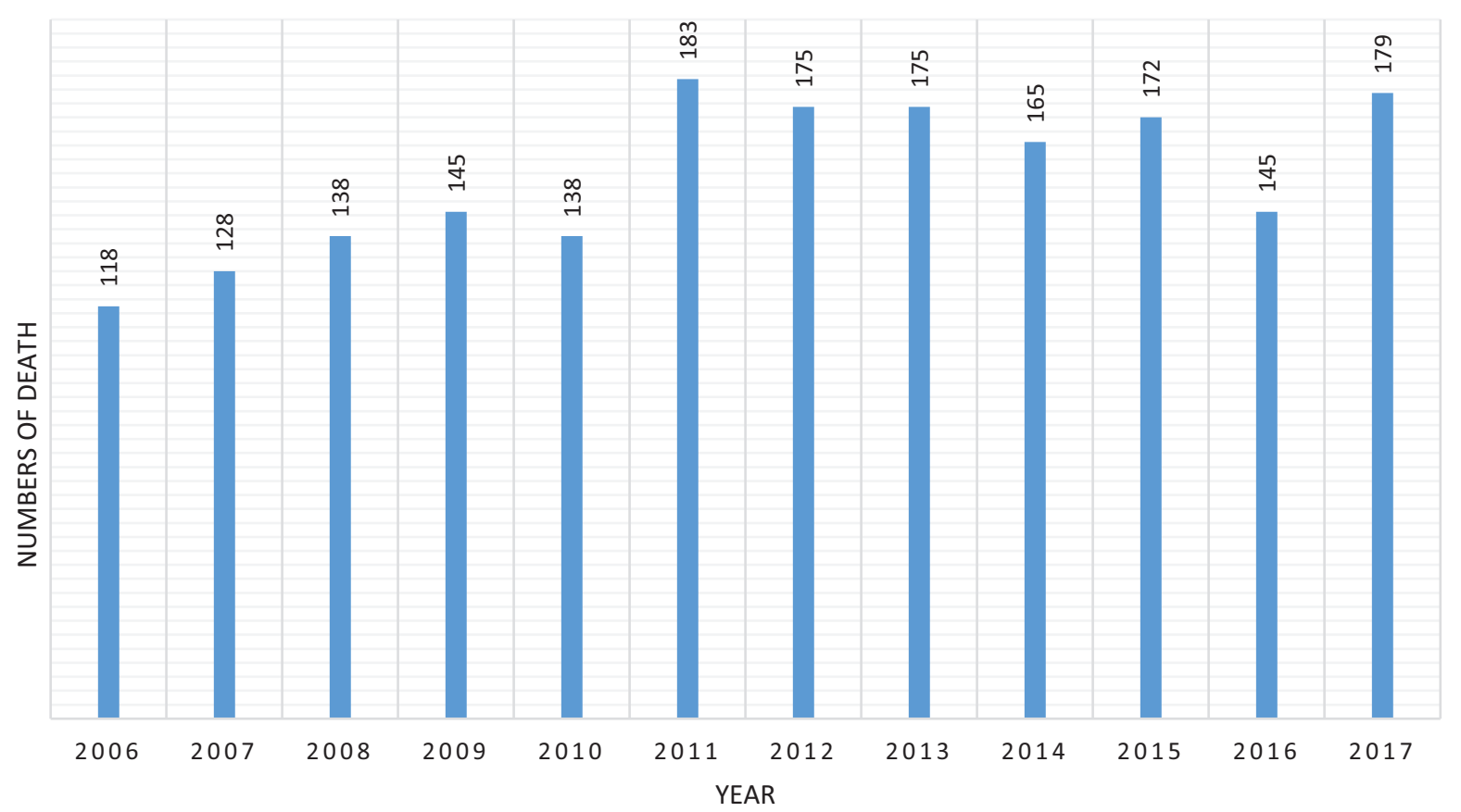

Fig. 2: Numbers of death due to construction accidents in Bangladesh (Ahmed et al. 2018a). 


\section{Background study}

Construction industry has encountered the highest number of fatal accidents among all other industries in the world (Albert and Hallowell 2012). Thus, studying the causes of accidents in construction projects has gained increasing importance to researchers in recent years although there is no research conducted before on the same context for the Bangladeshi construction industry. However, many studies have been conducted in this area in different parts of the world.

Cheng and $\mathrm{Wu}$ (2013) analyzed the characteristics of construction accidents in small projects in Taiwan using descriptive statistics and correlation coefficients. They discovered that the most critical cause of accidents was careless acts about the implementation of safety measures at project sites, followed by insufficient safety training for novice workers, the absence of competent health and safety professionals, proper attention from the authority to safety issue and lack of safety awareness. In Malaysia, Abdul Rahim Abdul Hamid (Hamid et al. 2008) identified a good number of causes of accidents at his research. The main causes of accidents were revealed, such as unsafe equipment, condition of job sites, unique nature of industry, unsafe method, management, poor safety policies, personal protective equipment (PPE), working at high elevation, poor site management and equipment failure. Priyadarshani et al. (2013) developed a safety assessment framework for the construction industry in Sri Lanka. According to their study, lack of commitment of management, lack of safety measure, negligence of individuals to respond to proper safety practices and unskilled worker were the most important factors leading to accidents at sites. Work at high elevation, poor site management, equipment failure, lack of skill and experience of executive and lack of worker training are the important causes that work behind construction accident in the United Arab Emirates (Al-Kaabi and Hadipriono 2003). Udo et al. (2016) revealed the major causes of construction accidents in Nigeria, and these are lack of safety measure while handling materials/objects and lifting materials/objects, slips, trip on object, operating damaged equipment, struck by moving objects, struck by moving machine/ equipment, caving in of excavations and fall from height. Haslam et al. (2005) illustrated that accidents occur as a result of the poor interaction between workers or work team (worker behaviour), workplace (poor housekeeping and material storing) and materials/equipment (PPE) that originate due to insufficiency in the construction design and process, project and risk management, customer/ owner and economic effects, or safety education and training. Ogwueleka (2013b) conducted a comprehensive literature review to analyze the causes of construction accident and pointed out the most influencing factors as management commitment, safety awareness of top management/project managers, errors in judgment or carelessness, expert knowledge or training, poor machinery and safety management practices/procedure/review.

\section{Methods and materials}

The primary objectives of this study were to identify and prioritize the causes of construction accidents in the Bangladeshi construction industry. To perform this study, a wide literature review for designing a questionnaire and questionnaire survey method to collect data were used. This research method was used because of its ability to collect an extensive range of agreement from individuals, to deal with a large number of respondents and to have better generalizability of the results. Figure 3 illustrates the method and process of this study.

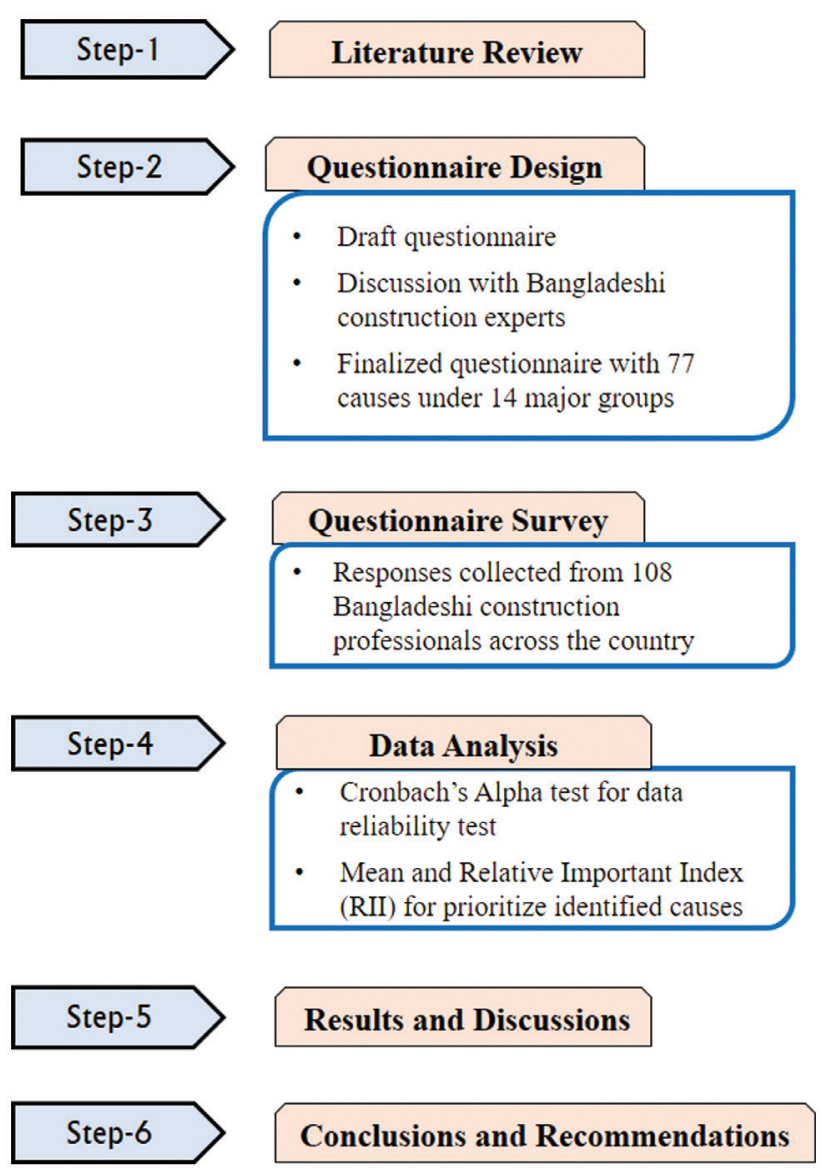

Fig. 3: Research flowchart. 


\subsection{Questionnaire design}

To identify the causes of construction accident in Bangladesh, a deep and broad literature review was conducted for sorting out a draft. After this, an open discussion was conducted with an expert panel (the panel consisted of government officials, high officials from Non-Governmental Organization (NGO), executives of labour organization, experienced contractors, engineers, project managers, university professors and university students) to identify the causes that are appropriate for the aspect of the Bangladeshi construction industry. A total of 77 causes were identified under 14 major groups for the construction accidents in Bangladesh.

A questionnaire survey was used to elicit the attitude of owners, consultants, labourers and contractors towards the factors influencing accidents in the construction projects in Bangladesh. The questionnaire was designed with two major parts. Part I was about the background information of the respondents. In part II, the respondents were asked to evaluate, based on their local experience, each of the identified 77 causes under 14 major groups that influences accidents on a 7-point Likert scale: (1) strongly disagree, (2) disagree, (3) moderately disagree, (4) neutral, (5) moderately agree, (6) agree and (7) strongly agree.

\subsection{Data collection}

The necessary data were collected through the questionnaire survey from the construction workers by visiting construction sites, labour unions, construction companies, government agencies and so on. A total of 147 questionnaires were distributed as follows: 44 to workers, 27 to owners, 41 to consultants and 35 to contractors. In all, 108 questionnaires (73.5\%) were returned as follows: 32 from workers, 23 from owners, 28 from consultants, and 25 from contractors as respondents. Table 1 gives the background information about the respondents. Authors concentrated on Institute of Engineers Bangladesh (IEB), Institute of Architects Bangladesh (IAB), Real Estate \& Housing Association of Bangladesh (REHAB) and Imarat Nirman Sramik Union Bangladesh (INSUB) to select the potential respondents. The IEB is the largest professional association of the country consisting of civil engineers, building engineers and construction managers. The IAB is the professional association of architects in Bangladesh. The REHAB is another largest platform of construction companies and firms with a good organizational set-up (high managerial level, including experienced professionals). The INSUB (in English, Building Construction Worker Association Bangladesh) is the country's only organization that works for the right, safety and others issues of workers in Bangladesh.

\subsection{Data analysis}

The relative important index (RII) is used for the determination of the rank between the 77 causes. Many studies used this method to rank and prioritize the variables (Ahmed et al. 2018a; Chiang et al. 2017; Enshassi et al. 2009; Williams et al. 2019; Winge and Albrechtsen 2018). This study has also chosen the same method to determine the ranks of causes. An equation mentioned in the following is used to determine the value of RII for each cause. Equation 1 is used in many research for the determination of impotency and relative rank (Hamid et al. 2014; Ogwueleka 2013a; Le-Hoai et al. 2008).

Tab. 1: Background information of the respondents

\begin{tabular}{|c|c|c|}
\hline Demographic Characteristics & Frequency & Percentage \\
\hline \multicolumn{3}{|l|}{ Sex } \\
\hline Male & 89 & 82 \\
\hline Female & 19 & 18 \\
\hline \multicolumn{3}{|l|}{ Age, years } \\
\hline$\leq 20$ & 31 & 29 \\
\hline $21-30$ & 15 & 14 \\
\hline $31-40$ & 25 & 23 \\
\hline$\geq 40$ & 37 & 34 \\
\hline \multicolumn{3}{|l|}{ Education } \\
\hline Lower higher secondary school & 42 & 39 \\
\hline Pre-university & 19 & 17 \\
\hline Graduate & 30 & 28 \\
\hline Postgraduate & 17 & 16 \\
\hline \multicolumn{3}{|l|}{ Location } \\
\hline Dhaka division & 28 & 23 \\
\hline Rajshahi and Rangpur divisions & 19 & 18 \\
\hline Chittagong division & 18 & 17 \\
\hline Sylhet division & 15 & 14 \\
\hline Khulna and Barisal divisions & 30 & 28 \\
\hline \multicolumn{3}{|l|}{ Type of organization } \\
\hline Owners & 23 & 21 \\
\hline Consultants & 28 & 26 \\
\hline Contractors & 25 & 23 \\
\hline Workers & 32 & 30 \\
\hline \multicolumn{3}{|l|}{ Working experience, years } \\
\hline$\leq 5$ & 19 & 18 \\
\hline $5-15$ & 30 & 28 \\
\hline $15-25$ & 23 & 21 \\
\hline$\geq 25$ & 36 & 33 \\
\hline \multicolumn{3}{|l|}{ Fields of specializations } \\
\hline Building & 89 & 51 \\
\hline Roads and bridge & 48 & 27 \\
\hline Electrical and mechanical & 22 & 13 \\
\hline Others & 17 & 09 \\
\hline
\end{tabular}




$$
\text { Relative Importance Index }(\mathrm{RII})=\frac{\sum W}{A \times N}
$$

In equation (1), $W$ is the weight given to each factor by the respondents (ranging from 1 to 7 ), $A$ is the highest weight (i.e. 7 in this case), and $N$ is the total number of respondents in this study (i.e. 108 in this study).

The mean of the causes is calculated in the way of normal average/mean. The mean for each cause was calculated by Microsoft Excel Worksheet 2016.

\subsection{Data validation test}

The required data for analysis of causes of construction accidents were collected independently from various respondents of various designations and organizations. Hence, it is necessarily important to check the reliability and validity of the independently collected data. The Cronbach's alpha $(\alpha)$ value was calculated to test the internal consistency of the scale in providing appropriate ratings for the design parameters and is an important factor in design consideration. George and Mallery (2016) and Pallant (2016) indicated that " $\alpha \geq 0.7$ " is acceptable, but values of " $\alpha>0.8$ " are more preferable. In this study, the Cronbach's $\alpha$ test was conducted using the Statistical Package for the Social Sciences (SPSS) 23 software. The collected independent data were inputted in the SPSS 23 and defined and set up the variable. Then, the calculation was processed from the "analysis" option and then "scale" to "reliability test".

From Table 2, the Cronbach's $\alpha$ coefficient was determined as 0.906, whereas the acceptable limit is 0.7. The collected data are excellent for the high stakes testing, and some advance test results are generated from this data validly.

\section{Analysis of results and discussion}

In this study, 77 causes under 14 major causes are identified. A large number of accidents at the construction sites are taking place in Bangladesh. A large number of people died in accidents in construction projects in Bangladesh. In Bangladesh, behind a large number of accidents, these

Tab. 2: Reliability statistics test for the collected data

\begin{tabular}{lcc}
\hline $\begin{array}{l}\text { Cronbach's } \\
\text { Alpha }(\alpha)\end{array}$ & $\begin{array}{c}\text { Cronbach's } \alpha \text { Based on } \\
\text { Standardized items }\end{array}$ & No of Items \\
\hline 0.906 & $\geq 0.7$ & 108 \\
\hline
\end{tabular}

77 causes are responsible directly and indirectly in many ways. Which one has got more pervasiveness by the respondents than others? This question is answered by the mean, RII of each cause and the RII-based ranks. The 77 causes of accidents at the construction sites are not as same as for all respondent groups. Different respondent groups expressed different types of agreement towards the causes. So ranks given by them for the causes of accidents are not the same. For revealing the actual scenario of accidents to various stakeholders of construction projects, it is essential to know the opinion of all groups of respondents towards each cause of accident. Table 3 gives the summary of mean, RII and RII-based rank of each

Tab. 3: Summary of mean, relative importance index (RII) and rank of causes of accidents in construction projects

\begin{tabular}{|c|c|c|c|c|}
\hline Causes of Accident & Mean & RII & $\begin{array}{c}\text { Rank } \\
\text { (Overall) }\end{array}$ & $\begin{array}{l}\text { Rank } \\
\text { (Within } \\
\text { the Major } \\
\text { Group) }\end{array}$ \\
\hline \multicolumn{5}{|l|}{ Project related } \\
\hline Value of project & 4.648 & 0.581 & 43 & 3 \\
\hline $\begin{array}{l}\text { Poor planning/scheduling of } \\
\text { project }\end{array}$ & 4.536 & 0.567 & 48 & 4 \\
\hline Very tight project schedule & 4.848 & 0.606 & 26 & 2 \\
\hline Type and nature of project & 5.000 & 0.625 & 19 & 1 \\
\hline $\begin{array}{l}\text { Social and communal } \\
\text { involvement of project }\end{array}$ & 4.064 & 0.508 & 71 & 5 \\
\hline $\begin{array}{l}\text { Financial body (government } \\
\text { or private) }\end{array}$ & 3.648 & 0.456 & 77 & 6 \\
\hline \multicolumn{5}{|l|}{ Site condition related } \\
\hline $\begin{array}{l}\text { Project site conditions } \\
\text { (exclude equipment, materi- } \\
\text { als, weather) }\end{array}$ & 4.536 & 0.567 & 49 & 3 \\
\hline Project site layout/space & 4.520 & 0.565 & 51 & 4 \\
\hline $\begin{array}{l}\text { Project working environment } \\
\text { (light/noise/hot/cold/wet) }\end{array}$ & 4.752 & 0.594 & 33 & 2 \\
\hline Poor housekeeping & 4.872 & 0.609 & 23 & 1 \\
\hline \multicolumn{5}{|l|}{ Contract related } \\
\hline $\begin{array}{l}\text { Not strict operation proce- } \\
\text { dures in contract }\end{array}$ & 5.152 & 0.644 & 12 & 1 \\
\hline $\begin{array}{l}\text { Coordination between } \\
\text { project participants }\end{array}$ & 4.272 & 0.534 & 70 & 5 \\
\hline $\begin{array}{l}\text { Lack of management commit- } \\
\text { ment in contract }\end{array}$ & 4.456 & 0.557 & 54 & 3 \\
\hline Type of awarding contract & 4.344 & 0.543 & 66 & 4 \\
\hline $\begin{array}{l}\text { Unclear contract conditions } \\
\text { on safety issue }\end{array}$ & 4.680 & 0.585 & 40 & 2 \\
\hline \multicolumn{5}{|l|}{ Design related } \\
\hline Design is not constructible & 4.384 & 0.548 & 61 & 3 \\
\hline $\begin{array}{l}\text { Incompleteness and incon- } \\
\text { sistency of design document }\end{array}$ & 4.360 & 0.545 & 65 & 4 \\
\hline $\begin{array}{l}\text { Safety is not considered } \\
\text { when designing }\end{array}$ & 5.056 & 0.632 & 17 & 2 \\
\hline
\end{tabular}


Tab. 3: Continued.

\begin{tabular}{|c|c|c|c|c|}
\hline Causes of Accident & Mean & RII & $\begin{array}{c}\text { Rank } \\
\text { (Overall) }\end{array}$ & $\begin{array}{l}\text { Rank } \\
\text { (Within } \\
\text { the Major } \\
\text { Group) }\end{array}$ \\
\hline $\begin{array}{l}\text { Lack of safety eliminating/ } \\
\text { avoiding design }\end{array}$ & 5.352 & 0.669 & 3 & 1 \\
\hline \multicolumn{5}{|l|}{ Material related } \\
\hline $\begin{array}{l}\text { Lack of protection in material } \\
\text { carrying }\end{array}$ & 3.832 & 0.479 & 76 & 5 \\
\hline $\begin{array}{l}\text { Lack of protection in material } \\
\text { storage }\end{array}$ & 5.064 & 0.633 & 15 & 1 \\
\hline $\begin{array}{l}\text { Working with toxic/hazard- } \\
\text { ous materials }\end{array}$ & 4.464 & 0.558 & 53 & 3 \\
\hline Hazard during transportation & 4.824 & 0.603 & 28 & 2 \\
\hline $\begin{array}{l}\text { Lack of knowledge about } \\
\text { construction materials }\end{array}$ & 4.448 & 0.556 & 55 & 4 \\
\hline \multicolumn{5}{|l|}{ Cost and time related } \\
\hline $\begin{array}{l}\text { Cost overrun reduce the } \\
\text { safety cost }\end{array}$ & 3.952 & 0.494 & 73 & 3 \\
\hline $\begin{array}{l}\text { Schedule delays and rework } \\
\text { in construction project }\end{array}$ & 4.376 & 0.547 & 62 & 2 \\
\hline $\begin{array}{l}\text { Short time assigned to worker } \\
\text { Consultant related }\end{array}$ & 4.768 & 0.596 & 31 & 1 \\
\hline $\begin{array}{l}\text { Lack of management/leader- } \\
\text { ship skills }\end{array}$ & 4.760 & 0.595 & 32 & 3 \\
\hline $\begin{array}{l}\text { Lack of knowledge and } \\
\text { experience }\end{array}$ & 4.320 & 0.540 & 68 & 6 \\
\hline $\begin{array}{l}\text { Unawareness of construction } \\
\text { safety }\end{array}$ & 5.160 & 0.645 & 11 & 2 \\
\hline Irregular investigation & 5.272 & 0.659 & 6 & 1 \\
\hline $\begin{array}{l}\text { Flexible to contractor/worker } \\
\text { on safety issue }\end{array}$ & 4.408 & 0.551 & 60 & 5 \\
\hline $\begin{array}{l}\text { No interest to change the } \\
\text { safety culture } \\
\text { Contractor related }\end{array}$ & 4.744 & 0.593 & 34 & 4 \\
\hline $\begin{array}{l}\text { Inaccurate or incomplete } \\
\text { schedule }\end{array}$ & 4.632 & 0.579 & 44 & 4 \\
\hline $\begin{array}{l}\text { Unawareness of safety- } \\
\text { related issue }\end{array}$ & 5.488 & 0.686 & 1 & 1 \\
\hline $\begin{array}{l}\text { Unwilling to spend safety- } \\
\text { related cost }\end{array}$ & 5.136 & 0.642 & 13 & 2 \\
\hline $\begin{array}{l}\text { Lack of skill and experience } \\
\text { of site staff }\end{array}$ & 4.288 & 0.536 & 69 & 6 \\
\hline $\begin{array}{l}\text { Violating Bangladesh National } \\
\text { Building Code (BNBC) code/ } \\
\text { Bangladesh labour law }\end{array}$ & 4.712 & 0.589 & 38 & 3 \\
\hline $\begin{array}{l}\text { Reckless action of contractor } \\
\text { Labourer related }\end{array}$ & 4.592 & 0.574 & 46 & 5 \\
\hline $\begin{array}{l}\text { Lack of collaboration among } \\
\text { labourers }\end{array}$ & 4.664 & 0.583 & 41 & 6 \\
\hline $\begin{array}{l}\text { Lack of personal protective } \\
\text { equipment }\end{array}$ & 5.392 & 0.674 & 2 & 1 \\
\hline Unskilled labourers & 5.216 & 0.652 & 10 & 3 \\
\hline $\begin{array}{l}\text { Worker empowerment to } \\
\text { make decision }\end{array}$ & 4.480 & 0.560 & 52 & 7 \\
\hline Poor education of labourers & 4.440 & 0.555 & 56 & 8 \\
\hline
\end{tabular}

Tab. 3: Continued.

\begin{tabular}{|c|c|c|c|c|}
\hline Causes of Accident & Mean & RII & $\begin{array}{c}\text { Rank } \\
\text { (Overall) }\end{array}$ & $\begin{array}{l}\text { Rank } \\
\text { (Within } \\
\text { the Major } \\
\text { Group) }\end{array}$ \\
\hline $\begin{array}{l}\text { Lack of expertise, knowledge } \\
\text { or training }\end{array}$ & 5.256 & 0.657 & 8 & 2 \\
\hline Interference with others' role & 4.344 & 0.543 & 67 & 9 \\
\hline Overtime for labourers & 4.840 & 0.605 & 27 & 5 \\
\hline Behaviour of workers & 4.880 & 0.610 & 22 & 4 \\
\hline \multicolumn{5}{|l|}{ Owner related } \\
\hline $\begin{array}{l}\text { Unwilling to pay extra cost } \\
\text { for safety }\end{array}$ & 5.240 & 0.655 & 9 & 1 \\
\hline $\begin{array}{l}\text { Owner's interference on } \\
\text { schedule and process }\end{array}$ & 4.000 & 0.500 & 72 & 4 \\
\hline $\begin{array}{l}\text { Variation in owner's expec- } \\
\text { tations }\end{array}$ & 3.864 & 0.483 & 74 & 5 \\
\hline $\begin{array}{l}\text { Lack of owner's emphasis on } \\
\text { safety }\end{array}$ & 4.368 & 0.546 & 64 & 3 \\
\hline $\begin{array}{l}\text { Owner's late response (deci- } \\
\text { sion making) }\end{array}$ & 4.368 & 0.546 & 63 & 2 \\
\hline \multicolumn{5}{|l|}{ Equipment and tools related } \\
\hline Unfit equipment & 5.328 & 0.666 & 4 & 3 \\
\hline Poor equipment maintenance & 5.056 & 0.632 & 16 & 6 \\
\hline Unuse of modern equipment & 4.856 & 0.607 & 24 & 5 \\
\hline $\begin{array}{l}\text { High cost of advanced equip- } \\
\text { ment and tools }\end{array}$ & 4.984 & 0.623 & 20 & 4 \\
\hline Improper use of equipment & 5.040 & 0.630 & 18 & 2 \\
\hline $\begin{array}{l}\text { Lack of knowledge and train- } \\
\text { ing on equipment } \\
\text { Management related }\end{array}$ & 5.320 & 0.665 & 5 & 1 \\
\hline $\begin{array}{l}\text { Lack of effective project } \\
\text { supervision }\end{array}$ & 4.856 & 0.607 & 25 & 2 \\
\hline $\begin{array}{l}\text { Lack of effective communi- } \\
\text { cation }\end{array}$ & 4.704 & 0.588 & 39 & 6 \\
\hline Inadequate safety policy & 5.264 & 0.658 & 7 & 1 \\
\hline Improper auditing system & 4.728 & 0.591 & 36 & 5 \\
\hline Poor organization structure & 4.656 & 0.582 & 42 & 7 \\
\hline Lack of information flow & 4.728 & 0.591 & 35 & 4 \\
\hline Lack of technique guide & 4.424 & 0.553 & 58 & 8 \\
\hline Lack of teamwork & 4.784 & 0.598 & 30 & 3 \\
\hline \multicolumn{5}{|l|}{ Technology related } \\
\hline Unuse of safety control system & 5.088 & 0.636 & 14 & 1 \\
\hline Unuse of schedule system & 3.848 & 0.481 & 75 & 6 \\
\hline $\begin{array}{l}\text { Unaware to advanced tech- } \\
\text { nology for safety }\end{array}$ & 4.544 & 0.568 & 47 & 4 \\
\hline $\begin{array}{l}\text { Lack of implementation } \\
\text { of Building Information } \\
\text { Modeling (BIM) }\end{array}$ & 4.896 & 0.612 & 21 & 2 \\
\hline Lack of innovation technology & 4.600 & 0.575 & 45 & 3 \\
\hline $\begin{array}{l}\text { Lack of implementing safety } \\
\text { control sensor technology }\end{array}$ & 4.408 & 0.551 & 59 & 5 \\
\hline \multicolumn{5}{|l|}{ External related } \\
\hline Act of God & 4.440 & 0.555 & 57 & 4 \\
\hline External obstacle/barrier & 4.528 & 0.566 & 50 & 3 \\
\hline Nature of construction & 4.720 & 0.590 & 37 & 2 \\
\hline Bad weather & 4.808 & 0.601 & 29 & 1 \\
\hline
\end{tabular}


cause for four respondent groups: workers, contractors, owners and consultants.

\subsection{High-ranking causes}

There are some causes are identified in this study which are very influencing to occurring accident at the construction sites in Bangladesh. And these accident bring out a large number of deaths for each year. In Table 4, the top ten (10) high-ranked causes from the different major group of causes are shown based on their RII value.

Table 4 indicates that the topmost crucial cause of construction accidents in Bangladesh is contractors being unawareness of safety-related issue $(\mathrm{RII}=0.686)$. Most of the contractors do not know the safety regulations properly, and they do not practice safety policy either. The law enforcement agencies are also not strict about the safety regulations in the construction sites. For this, those who know about safety take the opportunity to avoid it and those who do not know are not interest to know it. Respondents suggested that if contractors are made aware of construction safety regulations and safety practicing culture in the construction projects, $35 \%$ of accidents can be reduced in Bangladesh. So it the biggest challenge for

Tab. 4: Summary of high-ranking causes of accidents

\begin{tabular}{|c|c|c|c|c|}
\hline Causes & Major group & Mean & $\begin{array}{c}\text { Relative } \\
\text { importance } \\
\text { index (RII) }\end{array}$ & Rank \\
\hline $\begin{array}{l}\text { Unawareness of } \\
\text { safety-related issue }\end{array}$ & Contractor & 5.488 & 0.686 & 1 \\
\hline $\begin{array}{l}\text { Lack of personal } \\
\text { protective equipment }\end{array}$ & Labourer & 5.392 & 0.674 & 2 \\
\hline $\begin{array}{l}\text { Lack of safety } \\
\text { eliminating/avoiding } \\
\text { design }\end{array}$ & Design & 5.352 & 0.669 & 3 \\
\hline Unfit equipment & $\begin{array}{l}\text { Equipment and } \\
\text { Tools }\end{array}$ & 5.328 & 0.666 & 4 \\
\hline $\begin{array}{l}\text { Lack of knowledge } \\
\text { and training on } \\
\text { equipment }\end{array}$ & $\begin{array}{l}\text { Equipment and } \\
\text { Tools }\end{array}$ & 5.320 & 0.665 & 5 \\
\hline $\begin{array}{l}\text { Irregular } \\
\text { investigation }\end{array}$ & Consultant & 5.272 & 0.659 & 6 \\
\hline $\begin{array}{l}\text { Inadequate safety } \\
\text { policy }\end{array}$ & Management & 5.264 & 0.658 & 7 \\
\hline $\begin{array}{l}\text { Lack of expertise, } \\
\text { knowledge or } \\
\text { training }\end{array}$ & Labourer & 5.256 & 0.657 & 8 \\
\hline $\begin{array}{l}\text { Unwilling to pay } \\
\text { extra cost for safety }\end{array}$ & Owner & 5.240 & 0.655 & 9 \\
\hline Unskilled labourers & Labourer & 5.216 & 0.652 & 10 \\
\hline
\end{tabular}

the authorities to train and educate contractors with safety effects, advantages, regulations and laws. By knowing the effects of accidents, the death rate of accidents, violating punishment of safety regulation and practice the safety culture in construction project the contractors are made aware of this issue and a significant improvement could be happened to the accident scenario in Bangladesh. The second highest cause is lack of PPE of workers (RII = 0.674). A large number of workers are unskilled and do not know about construction safety. They even do not get any professional training in their work. Shakil et al. (Ahmed et al. 2018b) show that only $9.35 \%$ of Bangladeshi workers know and practice safety regulation and others do not. They also show that $9.68 \%$ of workers use PPE and the rest of the people do not use. A large number of accidents can be prevented if workers use PPE properly. So it is necessary to educate and train workers on construction safety and frame strict and punishable rules on PPE to reduce the accident rate. The third and fourth highest-ranked causes are lack of safety design $(\mathrm{RII}=0.669)$ and unfit equipment use in the construction work, respectively (RII $=0.666$ ). Contractors and owners are not interested to develop safety design along with detail drawing of projects. Safety design at the planning and design phase can be the change maker of accident rate. Respondents report that safety design is not adopted by the stakeholders due to extra cost for safety design, unawareness of safety design, lack of information about safety design, uncultured environment of safety design and so on. The fourth ranked cause is very much responsible for accidents, especially of workers and technicians. More than 35\% of accidents occur due to unfit equipment at the construction sites (Bourassa et al. 2016). So respective authorities, supervisors and safety managers have to be serious about the proper testing of equipment before the actual work starts

The fifth highest-ranked cause is lack of knowledge and training on equipment (RII $=0.665)$. As most of the workers and operators are poor at professional training and safety knowledge, so this cause is common and impactful to the construction accidents. The irregular investigation by consultants $(\mathrm{RII}=0.659)$ and inadequate safety policy adopted by management $(\mathrm{RII}=0.658)$ are determined as sixth and seventh ranked causes. These two causes purely indicate the vulnerable and poor state of management systems in the construction projects. More than $40 \%$ of the construction accidents could be mitigated by implementing appropriate and effective management policy in the construction industry (Reason 2016). Other causes mentioned in Table 4 are lack of expertise, knowledge or training of worker $(\mathrm{RII}=0.657)$, owner unwilling to pay an extra cost for safety $(\mathrm{RII}=0.655)$ and unskilled labourer 
$(\mathrm{RII}=0.652)$. These causes also have a high impact on accidents at the construction sites. For successful implementation of safety policy in organizations by reducing accident, training and workshop have to provide to the workers which make them aware and skilled on safetyrelated issues (Endroyo et al. 2015). Owners must have the willingness to sanction safety-related cost. Scarcity in safety-related cost has a great influence on construction accidents, and this cause is common in many countries, especially in developing and underdeveloped one (Tam et al. 2004; Williams et al. 2019; Yiu et al. 2018). Workers are the primary victims of the construction accidents, and they are in physical contact with accidents than any other project participants in construction. So unskilled labourers are the prime factors responsible for occurrence of frequent accidents in the construction sites (Raheem and Issa 2016; Shibani et al. 2013; Zhou 2015).

\subsection{Low-ranking causes}

Among the initially identified 77 causes of accidents, some are determined as low-ranking causes for influencing accidents in the construction projects in Bangladesh. These low-ranking causes have been given in Table 3 . Table 5 shows the low-ranked causes in an ascending

Tab. 5: Summary of low-ranking causes of accidents

\begin{tabular}{|c|c|c|c|c|}
\hline Causes & $\begin{array}{l}\text { Major } \\
\text { group }\end{array}$ & Mean & $\begin{array}{c}\text { Relative } \\
\text { importance } \\
\text { index (RII) }\end{array}$ & Rank \\
\hline $\begin{array}{l}\text { Financial body (World } \\
\text { Bank (WB), Asian } \\
\text { Development Bank (ADB), } \\
\text { government or private) }\end{array}$ & Project & 3.648 & 0.456 & 77 \\
\hline $\begin{array}{l}\text { Lack of protection in } \\
\text { material carrying }\end{array}$ & Material & 3.832 & 0.479 & 76 \\
\hline Unuse of schedule system & Technology & 3.848 & 0.481 & 75 \\
\hline $\begin{array}{l}\text { Variation in owner's } \\
\text { expectations }\end{array}$ & Owner & 3.864 & 0.483 & 74 \\
\hline $\begin{array}{l}\text { Cost overrun reduce the } \\
\text { safety cost }\end{array}$ & $\begin{array}{l}\text { Cost and } \\
\text { time }\end{array}$ & 3.952 & 0.494 & 73 \\
\hline $\begin{array}{l}\text { Owner's interference on } \\
\text { schedule and process }\end{array}$ & Owner & 4.000 & 0.500 & 72 \\
\hline $\begin{array}{l}\text { Social and communal } \\
\text { involvement of project }\end{array}$ & Project & 4.064 & 0.508 & 71 \\
\hline $\begin{array}{l}\text { Coordination between } \\
\text { project participants }\end{array}$ & Contract & 4.272 & 0.534 & 70 \\
\hline $\begin{array}{l}\text { Lack of skill and experi- } \\
\text { ence of site staff }\end{array}$ & Contractor & 4.288 & 0.536 & 69 \\
\hline $\begin{array}{l}\text { Lack of knowledge and } \\
\text { experience }\end{array}$ & Consultant & 4.320 & 0.540 & 68 \\
\hline
\end{tabular}

order with their respective major group of causes according to mean and RII.

Table 4 indicates that the lowest-ranking (seventy-seventh) cause of the construction accidents in Bangladesh is financial body's decision and attitude (WB, ADP, government or private) with the RII $=0.456$. This cause is not so much impactful on occurring accidents because financial body's attitude is ignored in the Bangladeshi construction industry (Islam et al. 2015). The second lowest, the 76th cause, is lack of protection in material carrying (RII $=0.479$ ). This cause is determined as a low-ranking cause that has a little influence on accidents, while many researchers found it as mid to high ranking (Aulin and Ågren 2012; Chiang et al. 2017; Chong and Low 2014). Third and fourth lowest ranked causes are unuse of schedule system $(\mathrm{RII}=0.481)$ and variation in owner's expectations $(\mathrm{RII}=$ $0.483)$, respectively. These causes enhanced the accident rate but respondents think that their contribution is not enough to mark them as high-ranking causes. These are also considered as the low-ranking causes in Pakistan (Raheem and Issa 2016), UAE (Shibani et al. 2013), China (Tam et al. 2004) and Malaysia (Chong and Low 2014).

The other lowest ranking $\left(73^{\text {rd }}, 72^{\text {nd }}\right.$ and $\left.71^{\text {st }}\right)$ causes are cost overrun reduce by reducing the safety cost (RII = 0.494), owner's interference on schedule and process $(\mathrm{RII}=0.500)$ and social and communal involvement of project $(\mathrm{RII}=0.508)$. Aulin and Ågren (2012) stated that safety budget is reduced to control the cost overrun of many construction projects. It plays an important role in the construction accidents. Owner's interference on the schedule and construction process is also identified as a low-ranking cause in developing countries (Kheni et al. 2008; Priyadarshani et al. 2013). Effective social and communal involvement could reduce the accident rate significantly in developing and developed countries (Benite and Cardoso 2001; Chiang et al. 2017; Gambatese 1998). Rest of the top ten low-ranking causes (70th, 69th and 68th ranking causes) are coordination between project participants $(\mathrm{RII}=0.534)$, lack of skill and experience of site staff $(\mathrm{RII}=0.536)$ and lack of knowledge and experience of consultants (RII $=0.540)$. Coordination between project participants is identified as a low-ranking cause, but many researchers found it as a high-ranking cause and that it has a great impact on the construction accidents (Toole 2005; Williams et al. 2019). Beriha et al. (2012) stated that by improving skills and experiences of site staffs, construction accidents could be eliminated from the construction sites significantly. Consultant's experience and knowledge play an important role in the construction accidents as they are responsible for safety 
Tab. 6: High-ranking causes of accidents for worker and contractor groups

\begin{tabular}{|c|c|c|c|c|}
\hline \multirow{2}{*}{ Rank } & \multicolumn{2}{|l|}{ Worker group } & \multicolumn{2}{|l|}{ Contractor group } \\
\hline & Causes of accident & Major group & Causes of accident & Major group \\
\hline 1 & $\begin{array}{l}\text { Non-strict operation procedures in } \\
\text { contract }\end{array}$ & Contract & Lack of personal protective equipment & Labourer \\
\hline 2 & $\begin{array}{l}\text { Lack of safety eliminating/avoiding } \\
\text { design }\end{array}$ & Design & $\begin{array}{l}\text { Lack of knowledge and training on } \\
\text { equipment }\end{array}$ & Equipment and tools \\
\hline 3 & No interest to change the safety culture & Consultant & $\begin{array}{l}\text { Violating Bangladesh National Build- } \\
\text { ing Code (BNBC) code/Bangladesh } \\
\text { labour law }\end{array}$ & Contractor \\
\hline 4 & Unskilled labourers & Labourer & Inadequate safety policy & Management \\
\hline 5 & Unwilling to spend safety-related cost & Contractor & Unwilling to pay extra cost for safety & Owner \\
\hline 6 & Irregular investigation & Consultant & Unfit equipment & Equipment \\
\hline 7 & $\begin{array}{l}\text { Lack of expertise, knowledge or } \\
\text { training }\end{array}$ & Labourer & $\begin{array}{l}\text { Non-strict operation procedures in } \\
\text { contract }\end{array}$ & Contract \\
\hline 8 & Unfit equipment & Equipment and tools & $\begin{array}{l}\text { High cost of advanced equipment and } \\
\text { tools }\end{array}$ & Equipment and tools \\
\hline 9 & Lack of knowledge and experience & Consultant & Lack of management/leadership skills & Consultant \\
\hline 10 & Unawareness of safety-related issue & Contractor & Unawareness of safety-related issue & Contractor \\
\hline
\end{tabular}

design, planning and safety supervision and make a decision when necessary (Toole 2005).

\subsection{High-ranking causes for each respondent group}

From Table 6, it can be seen that the highest-ranked causes for the worker group are non-strict operation procedures in the contract. Lack of safety eliminating/avoiding design, no interest to change the safety culture, unskilled labourers, and unwilling to spend safety-related cost are also in the top five causes for the worker respondent group. The contractor group determines that lack of PPE of labour is the topmost crucial cause of influencing fatal accident at the construction sites. The other most important contributors influencing accidents for the contractor group are lack of knowledge and training on equipment, violating BNBC code/Bangladesh labour law, inadequate safety policy, unwilling to pay an extra cost for safety and unfit equipment.

In Table 7, the inadequate safety management policy is the highest-ranked cause of accidents for the owner group. Unfit equipment, lack of teamwork, non-strict operation procedures in contract, unawareness of safety-related issue and lack of PPE are also considered as great contributors for occurring fatal accidents at construction sites based on the owner aspect. The topmost critical cause for the consultant group is unfit equipment. The consultant group also pointed out that unawareness of safety-related issue, lack of knowledge and training on equipment, improper auditing system, and safety are not considered when the design is highly responsible for influencing fatal accidents at the construction sites in Bangladesh.

From the analysis of both tables, it is figured out that non-strict operation procedures in contract, lack of safety eliminating/avoiding design, no interest to change the safety culture, unskilled labourers, unwilling to spend safety-related cost, irregular investigation, lack of expertise, knowledge or training, unfit equipment, inadequate safety policy, ineffective audit and supervision system, and unawareness of safety-related issue are the most crucial causes for all respondent groups. These highranking causes also cover the discussion in Section 5.2.

\subsection{Analysis of major groups of causes}

\subsubsection{Project-related causes}

The project-related group consists of six causes that have a great influence on construction accidents in the Bangladeshi construction projects. This major group is ranked ineleventh for contractors and owners, twelfth for workers and consultants, and eleventh for all respondents in Table 8. From Table 3, it is seen that the type and nature of project is the highest-ranking cause within the project-related causes. It is also listed as the top 20 crucial causes of accidents in the construction projects. The second highest-ranked cause is very tight project schedule. The lowest-ranking cause is financial body 
Tab. 7: High-ranking causes of accidents for owner and consultant groups

\begin{tabular}{|c|c|c|c|c|}
\hline \multirow{2}{*}{ Rank } & \multicolumn{2}{|l|}{ Owner group } & \multicolumn{2}{|c|}{ Consultant group } \\
\hline & Causes of accident & Major group & Causes of accident & Major group \\
\hline 1 & Inadequate safety policy & Management & Unfit equipment & Equipment and tools \\
\hline 2 & Unfit equipment & Equipment and tools & Unawareness of safety-related issue & Contractor \\
\hline 3 & Lack of teamwork & Management & $\begin{array}{l}\text { Lack of knowledge and training on } \\
\text { equipment }\end{array}$ & Equipment and tools \\
\hline 4 & $\begin{array}{l}\text { Non-strict operation procedures in } \\
\text { contract }\end{array}$ & Contract & Improper auditing system & Management \\
\hline 5 & Unawareness of safety-related issue & Contractor & $\begin{array}{l}\text { Safety is not considered when } \\
\text { designing }\end{array}$ & Design \\
\hline 6 & Lack of personal protective equipment & Labourer & $\begin{array}{l}\text { Lack of expertise, knowledge or } \\
\text { training }\end{array}$ & Labour \\
\hline 7 & $\begin{array}{l}\text { Lack of knowledge and training on } \\
\text { equipment }\end{array}$ & Equipment and Tools & Inadequate safety policy & Management \\
\hline 8 & $\begin{array}{l}\text { Lack of safety eliminating/avoiding } \\
\text { design }\end{array}$ & Design & $\begin{array}{l}\text { Lack of management commitment in } \\
\text { contract }\end{array}$ & Contract \\
\hline 9 & Unskilled labourers & Labourer & $\begin{array}{l}\text { Lack of safety eliminating/avoiding } \\
\text { design }\end{array}$ & Design \\
\hline 10 & $\begin{array}{l}\text { Lack of management commitment in } \\
\text { contract }\end{array}$ & Contract & Unawareness of safety-related issue & Contractor \\
\hline
\end{tabular}

Tab. 8: Summary of ranking of major groups of causes

\begin{tabular}{|c|c|c|c|c|c|c|}
\hline \multirow{2}{*}{ Major group } & \multicolumn{4}{|c|}{ Ranks for each respondent groups } & \multicolumn{2}{|c|}{ Overall } \\
\hline & Contractor & Worker & Owner & Consultant & RII & Rank \\
\hline Project related & 11 & 12 & 11 & 12 & 0.548 & 11 \\
\hline Site condition related & 6 & 8 & 10 & 5 & 0.583 & 8 \\
\hline Contract related & 14 & 9 & 9 & 13 & 0.543 & 12 \\
\hline Design related & 9 & 11 & 6 & 11 & 0.568 & 9 \\
\hline Material related & 3 & 7 & 8 & 9 & 0.591 & 7 \\
\hline Cost and time related & 13 & 14 & 13 & 14 & 0.478 & 14 \\
\hline Consultant related & 5 & 4 & 2 & 6 & 0.625 & 4 \\
\hline Contractor related & 7 & 2 & 3 & 3 & 0.636 & 3 \\
\hline Labourer related & 4 & 6 & 5 & 2 & 0.607 & 5 \\
\hline Owner related & 12 & 13 & 12 & 10 & 0.508 & 13 \\
\hline Equipment and tools related & 2 & 5 & 1 & 4 & 0.658 & 2 \\
\hline Management related & 1 & 1 & 4 & 1 & 0.677 & 1 \\
\hline Technology related & 8 & 3 & 7 & 8 & 0.598 & 6 \\
\hline External related & 10 & 10 & 14 & 7 & 0.555 & 10 \\
\hline
\end{tabular}

profile (WB, ADP, government or private). The financial bodies have an influence on regulation and work procedure topic but are not as much as important as other causes within this major group. Project-related causes are significant in the construction sector over the world. Poor and tight scheduling, social involvement, financer profile and type of projects are very important elements of construction accidents in many countries (Report 2017; Yiu et al. 2018; Zhou 2015).

\subsubsection{Site condition-related causes}

Site-related group contains four important causes that are responsible for accidents in the construction projects. Form Table 8, it can be seen that this major group is ranked in sixth for contractors, eight for workers, fifth for consultants, tenth for owners and eighth for all respondents. Among the four causes, poor housekeeping is holding the highest position in Table 3. Respondents thought that poor 
housekeeping and project working environment (light/ noise/hot/cold/wet) are most important within this group. Project site conditions (excluding equipment, materials, weather) is determined as a moderately important cause. Project site layout/space holds the lowest-ranking position within the group in Table 3. It is clear that causes of this group are mid-ranked and have a moderate level of significance on influencing accidents at the construction sites. Chong and Low (2014) revealed that housekeeping and site layout play a very crucial role and considered them as key factors for the occurrence of accidents in construction sites. Project site condition and environment are also responsible for the high rate of construction accidents in developing countries (Priyadarshani et al. 2013). To reduce the accident rate, it is important to analyze and resolve the causes associated with this group by the construction professionals and authorities.

\subsubsection{Contract-related causes}

The contract-related group is ranked in fourteenth for contractors, ninth for workers and owners, thirteenth for consultants, and twelfth for all respondents in Table 8. This group is formed with five causes of accidents in the construction industry. Table 2 shows that the highest-ranking cause in this group is non-strict operation procedures in the contract. The second highest cause is unclear contract conditions on safety issue. Lack of management commitment in contract and type of awarding contract stand for the mid-ranking positions within this group. Coordination between project participants is determined as the lowest-ranking cause within this major group of causes. Most of the causes in the group have very low-ranking positions except non-strict operation procedures in the contract, which has the overall twelfth rank. Non-strict operation procedures and unclear safety policy in the contract are considered as the high-ranking causes in many studies (Hossain and Ahmed 2018; Kheni et al. 2008). These causes have a great impact on construction safety management in Bangladesh. Poor management commitment (Swuste et al. 2012) and poor coordination between stakeholders (Sanchez et al. 2017) also influence construction safety but in a low range. Consultants, owners and contractors have to alert about this group because most of the contract is signed by them.

\subsubsection{Design-related causes}

The design-related major group consists of four causes of accidents in the Bangladeshi construction projects given in Table 3. It is clear that among all the causes of the group, lack of safety eliminating/avoiding design holds the highest rank and has a great contribution to occurring accidents. It is also determined as the third highest-ranked cause among 77 causes. Safety is not considered when design is holding the second highest rank (seventeenth overall rank) for the noticeable contribution to enhance the accident rate. The mid-ranking cause within this group is design is not constructible. The lowest-ranking cause in this group is incompleteness and inconsistency of design document, which have a small influence on accidents in the construction projects. From Table 8, it can be seen that the design-related group is ranked in ninth for contractors, eleventh for workers and consultants, sixth for owners and ninth for all respondents. Safety is not considered when design and lack of safety eliminating/ avoiding design are the high-ranking causes within this group and is ranked inthird and seventeenth overall positions, respectively. These causes are also crucial in India (Unnikrishnan et al. 2015), Nigeria (Agbede et al. 2016), Sri Lanka (Priyadarshani et al. 2013) and Ghana (Kheni et al. 2008). Researchers (Baxendale and Jones 2000; Hongling et al. 2016) recommended that authorities should give prior attention to inconsistent, incomplete and complex design to reduce accidents in construction projects. Consultants and contractors are the key responsible people for any kind of design complexities in the construction projects. So consultants and contractors have to give more serious attention compared to owners and labourers to improve the fatal scenario due to accidents in the Bangladeshi construction industry.

\subsubsection{Material-related causes}

This group consists of five important causes of accidents in the construction projects in Bangladesh. From Table 3, it can be seen that lack of protection in material storage is determined as the highest-ranking cause within this group. Hazard during transportation and working with toxic/hazardous materials stood for second and third highest ranks, respectively, for their impotency of influencing accidents. Lack of knowledge about construction materials is a less important cause of accidents, and the lowest-ranking cause in this major group is lack of protection in material carrying. Material-related group is considered as a very important cause of accidents in the construction sites not only in Bangladesh but also all over the world (Jannadi and Bu-Khamsin 2002). Accidents occur by falling and moving materials, sharp materials, toxic materials, explosive materials, substandard materials and so on at the construction 
sites (Kartam and Bouz 1998). Jannadi and Bu-Khamsin (2002) suggested proving and ensuring adequate protection during materials carrying and storing to avoid fatal events in the construction projects. Working and transporting toxic/hazardous material increase the possibility of accidents in the construction sites significantly (Kartam and Bouz 1998; Priyadarshani et al. 2013). From Table 8, it can be seen that this group is ranked in third for contractors, seventh for workers, ninth for consultants, eighth for owners, and ninth for all respondents. Labourers work with materials with physical contact, consultants are responsible for testing and clearance, and contractors are responsible for choosing and purchasing the materials. Labourers, consultants and contractors are primarily responsible for material-related causes. So these respondent groups should give more attention to material-related causes to make an accident-free construction industry.

\subsubsection{Cost- and time-related causes}

In Table 8, this group is ranked in thirteenth for contractors and owners, fourteenth for workers and consultants, and fourteenth for all respondents. The cost- and timerelated group constitutes three causes of accidents in the Bangladeshi construction projects in Table 3. Short time assign to the worker is determined as the highest-ranking cause within this group. Schedule delays and rework in project stood for the second highest rank within this group. The lowest-ranking cause is cost overrun, which reduces the safety cost within this major group. Hossain and Ahmed (2018) pointed out that schedule delays and rework are very common in the Bangladeshi construction industry and play a crucial role in safety management in construction projects. Short time assigned to the worker is another important cause where the workers are hurried to complete the work, and this leads to a very vulnerable and accident-prone situation (Kheni et al. 2008; Star 2017). Aulin and Ågren (2012) stated that safety-related budget is reduced to control the cost overrun in many construction projects, and it hampers the safety management significantly in any construction project that experiences inadequate resources for safety.

\subsubsection{Consultant-related causes}

Consultant-related group consists of six weighted causes of accidents in the Bangladeshi construction project. Table 3 indicates that the highest-ranking cause within this group is irregular investigation. This cause is absolutely very important for accidents, and it is ranked insixth among the 77 causes. The second and third highest-ranking causes within this group are unawareness of construction safety and lack of management/leadership skills. No interest to change the safety culture and flexible to contractor/ worker on safety issue also play an important role in construction accidents in Bangladesh. The lowest-ranking cause is lack of knowledge and experience. On the other hand, this group is ranked in fifth for contractors, fourth for workers, sixth for consultants, second for owners, and fourth for all respondents in Table 8. Lack of knowledge, skill and awareness of safety is a very important factor that affects safety in construction and prompts accidents (Hongling et al. 2016; Priyadarshani et al. 2013). Regular investigation and new culture adaptation by consultants play a very significant role in the implementation of effective safety policy in construction projects (Toole 2005). So consultants should take action to resolve these causes of accidents to improve the safety and reduce the accident rate at the satisfactory level.

\subsubsection{Contractor-related causes}

The contractor-related major group is ranked in seventh for contractors, second for workers, third for consultants and owners and third for all respondents in Table 8. This major group is formed with the six intensive causes of accidents in the construction projects. Table 2 reveals that the highest-ranking cause among the group is unawareness of safety-related issue. The second highest-ranking cause is unwilling to spend safety-related cost within this group. Violating BNBC code/Bangladesh labour law and inaccurate or incomplete schedule hold midranking positions within this group. The lowest-ranking cause within this group is lack of skill and experience of site staff and reckless action of contractors. This group plays a very strong role behind the high accident rate in the Bangladeshi construction industry. Unawareness of safety and unwillingness to sanction safety resource are identified as high-ranking causes in many countries, and researchers recommended dealing with these causes in the best possible ways (Ahmed et al. 2018; Chong and Low 2014). Lack of skills and experiences, violating building code and reckless action of contractors play an important role and are considered as the dominating factors affecting safety in global construction (Chiang et al. 2017; Endroyo et al. 2015). Primarily, contractors are mostly responsible for these causes, and they have to deal in a serious manner with this group of causes to make an accident-free worksite. 


\subsubsection{Labourer-related causes}

The labourer-related major group constitutes nine furious causes of accidents in the construction projects in Bangladesh. Table 3 indicates that the highest-ranking cause within this group is lack of PPE. It is also determined as the second highest-ranking cause among 77 causes. The second and third highest important causes within this major group are lack of expertise, knowledge or training and unskilled worker, respectively. Lack of expertise, knowledge or training also obtained the eighth rank and unskilled worker stood for the 10th rank among overall 77 causes of accidents. Other important causes in this group are behaviour of workers, overtime for labourers, lack of collaboration among labourers and worker empowerment to make decision. The second lowest-ranking cause is poor education of labourers, and the lowest-ranking cause is interference with other's role within the labourer-related major group. It is clear from the respondent's perception that this major group is very much responsible for accidents in the construction projects in Bangladesh. Labourerrelated causes play a very crucial role in occurrence of frequent accidents in the Bangladeshi construction industry. Most of the developing countries considered this group as the main cause of accidents in the construction sites (Benite and Cardoso 2001). Lack of training, skills, awareness, teamwork and PPE is the principal factor that enhances the possibility of construction accidents and is the main barrier to implementing safety policy within construction organizations (Enshassi et al. 2009; Fang et al. 2015). All the causes of this group are responsible for accidents significantly, such as overtime arises stress and unconsciousness (Blyton et al. 2017), interference with other role hampers discipline and sequence of works (Akintayo 2010) and workers' attitude and behaviour is a very important element in safety management (Shin et al. 2014). Enshassi et al. (2009) stated that unskilled and uneducated workers are the principal elements for the occurrence of frequent accidents in the construction projects. The labourer-related major group is ranked in fourth for contractors, sixth for workers, second for consultants, fifth for owners and fifth for all respondents in Table 8. So it is clear that primarily labourers should seriously deal with this group to improve the accident scenario at the construction sites in Bangladesh.

\subsubsection{Owner-related causes}

From Table 8, it can be seen the owner-related major group is ranked in twelfth for contractors and owners, thirteenth for workers, tenth for consultants, and thirteenth for all respondents. This major group consists of five important causes of accidents in the construction projects in Bangladesh. The highest-ranking cause in this group is unwilling to pay extra cost for safety. This cause also stood for the ninth position among all 77 causes. Other important causes of this group are owner's late response (decision making), lack of owner's emphasis on safety and owner's interference on schedule and process within the owner-related major group of causes. The lowest-ranking cause within this group is variation in owner's expectations. Owner's late response, expectation variation and interference are the main owner-related causes that commonly appeared not only in Bangladesh but also in global construction industry (Gambatese et al. 2000; Huang and Hinze 2006; Wu et al. 2015). Huang and Hinze (2006) stated that if owners emphasize on safety and sanction budget for it, a large portion of construction accident could be reduced. The owners are mostly liable for these causes and have to deal with this cause group to reduce the accident rate and improve the safety.

\subsubsection{Equipment and tool-related causes}

In Table 8, the equipment and tool-related major group is ranked in second for contractors, first for owners, fifth for workers, fourth for consultants and second for all respondents. This major group consists of six crucial causes of accidents in Table 3. This second highestranking group of causes is very dominating in the Bangladeshi construction industry. Unfit equipment and poor skills and training on equipment and tools are the highest-ranking causes within this group. These causes are very important causes not only in Bangladesh but also in other developing countries (Jannadi and Bu-Khamsin 2002; Kheni et al. 2008; Priyadarshani et al. 2013). Kartam and Bouz (1998) stated that fit equipment and proper training could reduce accidents remarkably. Poor maintenance and improper use of equipment are mid-ranked within this group and have a great influence in entire safety management of any construction site (Tam et al. 2004). The lowest-ranking causes within this group are unuse of modern equipment (Forbes and Ahmed 2010), and high cost of advanced equipment and tools (Li et al. 2018). So all respondents have to be serious about this major group, as it is the most devastating group that is highly responsible for the critical accident rate in Bangladesh. Authorities should give more priority to dealing with it to reduce the accident rate at the construction sites in Bangladesh. 


\subsubsection{Management-related causes}

The management-related major group is formed with eight causes of accidents in Table 3. The highest-ranking cause in this group is inadequate safety policy, and the second highest-ranking cause is lack of effective project supervision. Other important causes are lack of teamwork, lack of information flow, improper auditing system and lack of effective communication. The lowest-ranking causes within this group are poor organization structure and lack of technique guide. On the other hand, the management-related major group is ranked in first for contractors, workers and consultants; fourth for owners and first for all respondents in Table 8. This major group is the most responsible group influencing accidents in the construction projects in Bangladesh. It is determined as the most crucial group for a large number of accidents in Bangladesh. To reduce the accident rate and design an appropriate effective safety policy, authorities have to work within this group very closely with priority. Lack of effective communication and information flow (Lundgren and McMakin 2018), ineffective audit and supervision (Teo and Ling 2006), lack of technical guide and teamwork (Blyton et al. 2017; Unnikrishnan et al. 2015), poor organizational structure and inadequate safety policy (Aulin and Ågren 2012; Chiang et al. 2017; Chong and Low 2014; Endroyo et al. 2015) are the causes that should be seriously considered, and an effective safety program should be developed to eliminate accidents in the construction projects.

\subsubsection{Technology-related causes}

From Table 8, it can be seen that the technology-related major group is ranked in eighth for contractors and consultants, seventh for owners, third for workers and sixth for all respondents. This major group consists of six crucial causes of accidents. Table 3 indicates that the highestranking cause in this group is unuse of safety control system. Lack of implementation of BIM and lack of innovation in technology stood for the second and third positions within this group. Unawareness of advanced technology for safety and lack of implementing safety control sensor technology are also important in this major group. The lowest-ranking cause within this group is unuse of schedule system. By implementing BIM, innovative technologies and safety control sensor technologies, a large number of accidents could be prevented, detected and eliminated, as shown in many studies (Ahmed 2018; Forbes and Ahmed 2010; Karakhan et al. 2019). Unuse of safety control and scheduling system and lack of awareness of advanced technology also have a great impact on safety management and construction accident all over the world (Aulin and Ågren 2012; Enshassi et al. 2009; Gambatese 1998). Authorities have to get serious about this important major group and should try to solve these issues quickly.

\subsubsection{External-related causes}

According to Table 3, the external-related major group is formed with four intensive causes that influence accidents in the construction projects in Bangladesh. The highestranking cause is bad weather, and the second highestranking cause is nature of the construction within this major group of causes. The lowest-ranking cause is act of God, and the second lowest-ranking cause is external obstacle/barrier within this major group. The externalrelated major group is ranked in tenth for contractors and workers, fourteenth for consultants, seventh for owners and tenth for all respondents in Table 8. Act of God, nature of construction and bad weather are pointed out in many studies in the same context but not considered as high-ranking causes (Raheem and Issa 2016; Williams et al. 2019; Yu et al. 2014; Zhou 2015). The respondents are quite free from the liability of these causes but have to be careful about this group to design an effective safety policy.

\section{Conclusions and recommendations}

This study was designed to assess the perception of construction professionals regarding the key causes of construction accidents in the Bangladeshi construction industry. By conducting and analyzing a questionnaire survey, this study identified the key causes of construction accidents and prioritized them using RII. The survey was based on causes of accident extracted from findings of existing literature, together with socioeconomic factors specific to the Bangladeshi context that were identified through interviews with the Bangladeshi construction experts. Cronbach's $\alpha$ test was performed to validate the collected data for this study. Because of the high rate of construction accident and fatality, the main purpose of this study was to identify the causes of accidents at the construction sites in Bangladesh.

Among the 77 causes, contractor unawareness of safety-related issue is ranked in first position, lack of PPE of worker is ranked in second position and lack of safety 
eliminating/avoiding design and unfit equipment use in the construction work is ranked in third and fourth positions, respectively, as causes of accidents in the Bangladeshi construction industry. Lack of knowledge and training on equipment, irregular investigation by consultant, inadequate safety policy adopted by management and lack of expertise, knowledge or training of workers are also ranked high and are very impactful causes. The lowestranking causes are also determined in this study, and these are financial body (government or private), lack of protection in material carrying, unuse of schedule system, variation in owner's expectations, cost overrun reduce the safety cost and owner's interference on schedule and process. The highest-ranking causes for the contractors are lack of PPE and lack of knowledge and training on equipment. Non-strict operation procedures in contract and lack of safety eliminating/avoiding design are the highestranking causes for the workers. The highest-ranking causes for the consultants are unfit equipment and lack of knowledge and contractor unawareness of safetyrelated issue, while inadequate safety policy and unfit equipment are the highest-ranking causes for the owners.

This study also prioritizes the major groups of causes. The management-related cause group is ranked in first position, and equipment and tools-related group is ranked in second position. Other highest-ranking major groups are the contractor-, consultant- and labourerrelated groups of causes. The lowest-ranking major groups are the time and cost-, owner- and contract-related major groups of causes. The management-related major group is ranked in first for contractors, workers and consultants, while equipment and tools-related major group is ranked in first for the owners. The lowest-ranking major group is the cost and time-related major group for workers and consultants, contract-related major group for contractors and the external-related major group for owners.

There are no straightforward solutions to overcome the causes of accidents in the Bangladeshi construction industry. There are, however, systematic steps that can be taken to reduce their influence and effects. For the specific causes of the construction accidents in Bangladesh, the following recommendations are suggested:

- The different project stakeholders should review the clauses in the contract. A clear and transparent safety policy, standard operation procedures and specific job specification should be explicitly stipulated in the agreement, and the construction process should be actively supervised by the top management. In addition, it is recommended to prepare the payment schedule at the planning stage to ensure that all project participants are paid regularly.
- There is an exigent need for improving the management skills of the consultants, contractors, workers and construction site staff. Training and workshop programs should be established to provide concerning stakeholders the required skills and techniques concerning scheduling, cost and time control, equipment, technology and risk analysis.

- Adoption and adaptation of innovative and advanced management techniques such as lean construction, BIM, automation, total safety management and cloudbased facilities should be carried out. This idea may bring several benefits to the construction industry, especially in terms of implementing safety policy and culture and detecting, avoiding, and eliminating accident in construction projects.

- Owners are advised not to depend on lowest price contractors and consultants but to choose them according to their experience and technical qualification of staff in order to be able to follow the different managerial and technical aspects of the project. Owners should involve in the project from the earlier stage for avoiding change or variation in the middle of construction. Owners are also suggested to give emphasis on safety issue and to provide adequate resource for implementing effective safety management.

- Contractors are recommended to continuously monitor and control the standard, quality and schedule of construction equipment, materials and procedures continuously in order to avoid any mistakes that may lead to the risky, hazardous and unsafe situation. Contractors should provide adequate training and resource to workers and site staff including subcontractors. Contractors are also suggested to solve any design and documental complexities before the work starts.

- Consultants are advised to continuously supervise, monitor and control safety management in the construction sites and take action when necessary. Consultants should stick to the contracted commitment and inspect and test the equipment and materials used in the construction projects. Additionally, consultants are suggested to correct all design errors and to be straight and strict to contractor with professional ethics.

- Labourers are recommended to work with consciousness in relation to equipment, materials and other construction elements, safety measure (PPE), collaboration and teamwork. Labourer should avoid reckless attitude, freaky behaviour and interference with other roles in the construction sites. Additionally, labourers are suggested to show interest to get training and follow safety policy. 
- The Bangladeshi government should simplify administrative procedures for construction firms to reduce accidents and improve the safety for the permitting process. The government should establish strict laws for violating safety and relative regulations.

Further research should be performed to identify the most common causes of construction accidents in Bangladesh to develop an effective safety policy to the requirements of the Bangladeshi context. It is a suggestion to the future studies to identify and rank the causes in a more wide range such as those based on different characteristics of respondents like organizational characteristics (organization size, organization type, geographical area, annual revenue, public/private and national/multinational) and individual characteristics (educational qualification, working experience, specialized field of working, age and others). Future studies could be performed with the additional objective of identifying and analyzing the effects of accidents. This study has only chosen the potential respondents who are registered with IEB, IAB and REHAB (government-approved associations). There are many organizations and construction professionals who are not registered with these associations. Future research should consider these types of organizations and individuals as the potential sources of respondents, and this could give a more appropriate status of findings as it covers a large portion of the construction industry in Bangladesh. Future studies are recommended to cover a large number of respondents as possible, which gives a more compatible finding. Moreover, there is a primordial need to carry out case studies in different construction companies to conceive a roadmap for identifying and solving the causes of accident in the Bangladeshi construction industry. This study has performed with a wide scale of causes than available studies till today in global construction. The findings of this study could prove compatible with other South Asian and developing countries, especially those sharing similarities to the Bangladeshi context. Identifying the causes of construction accidents can help practitioners, companies and researchers in the global construction industry to focus their effort and resources on the significant issues necessary to assist a successful reduction of accident rate.

\section{References}

Agbede, JO, Manu, P, Agbede, OA, \& Mahamadu, A-M. (2016). Health and safety management practices in the Nigerian construction industry: A survey of construction firms in South Western Nigeria. Tampere University of Technology. Department of
Civil Engineering. Construction Management and Economics. Report, 2, 293-304.

Ahemd, S, \& Bashar, I. (2018). Analysis of accident on construction site in Bangladesh: A construction safety management issue part-I. (Bachelor of Science in Engineering Undergraduate), Khulna Khulna University of Engineering and Technology, Khulna, Bangladesh.

Ahmed, S. (2018). A review on using opportunities of augmented reality and virtual reality in construction project management. Organization, technology \& management in construction: an international journal, 10(1), pp. 1839-1852.

Ahmed, S, Bashar, I, \& Hoque, Md. I. (2018a). Analysis of accident on construction site in Bangladesh: A construction safety management issue part-II. (Bachelor of Science in Building Engineering and Construction Management), Khulna Khulna University of Engineering and Technology, Khulna.

Ahmed, S., Hoque, Md I., Islam, Md H., \& Hossain, M. (2018b). A reality check of status level of worker against skilled worker parameters for Bangladeshi Construction Industry. Journal of Civil Engineering and Construction, 7(3), pp. 132-140.

Ahmed, S, Sobuz, Md HR, \& Haque, Md I (2018c). Accidents on Construction Sites In Bangladesh: A Review. Paper presented at the 4th International Conference on Civil Engineering for Sustainable Development (ICCESD 2018), 9 11 February 2018, KUET, Khulna, Bangladesh.

Akintayo, D. I. (2010). Work-family role conflict and organizational commitment among industrial workers in Nigeria. International Journal of Psychology and Counselling, 2(1), pp. 1-8.

Al-Kaabi, N., \& Hadipriono, F. (2003). Construction safety performance in the United Arab Emirates. Civil Engineering and Environmental Systems, 20(3), pp. 197-212.

Albert, A, \& Hallowell, MR. (2012). Hazard recognition methods in the construction industry. Paper presented at the Construction Research Congress 2012: Construction Challenges in a Flat World.

Aulin, R, \& Ågren, R. (2012). Occupational accidents profile of the construction industry in Sweden. Paper presented at the Proceeding of CIB W099 Conference, Singapore, September, CIB, Rotterdam.

Aziz, R. F., \& Abdel-Hakam, A. A. (2016). Exploring delay causes of road construction projects in Egypt. Alexandria Engineering Journal, 55(2), pp. 1515-1539.

Baxendale, T., \& Jones, O. (2000). Construction design and management safety regulations in practice-progress on implementation. International Journal of Project Management, 18(1), pp. 33-40.

Benite, A. G., \& Cardoso, F. F. (2001). The implementation of occupational health and safety management systems in one construction company in Brazil. International Labour Organization, 100(3).

Beriha, G. S., Patnaik, B., Mahapatra, S. S., \& Padhee, S. (2012). Assessment of safety performance in Indian industries using fuzzy approach. Expert Systems with Applications, 39(3), pp. 3311-3323.

Biswas, G., Bhattacharya, A., \& Bhattacharya, R. (2017). Occupational health status of construction workers: a review. International Journal of Medical Science and Public Health, 6(4), pp. 669-675.

Blyton, P., Hassard, J., Hill, S., \& Starkey, K. (2017). Time, Work and Organization, Vol. 7. Taylor \& Francis, Routledge. 
Bourassa, D., Gauthier, F., \& Abdul-Nour, G. (2016). Equipment failures and their contribution to industrial incidents and accidents in the manufacturing industry. International Journal of Occupational Safety and Ergonomics, 22(1), pp. 131-141.

Burr, A. (2016). Delay and Disruption in Construction Contracts. CRC Press, Boca Raton.

Cheng, C.-W., \& Wu, T.-C. (2013). An investigation and analysis of major accidents involving foreign workers in Taiwan's manufacture and construction industries. Safety Science, 57, pp. 223-235.

Chiang, Y.-H., Wong, F. K.-W., \& Liang, S. (2017). Fatal construction accidents in Hong Kong. Journal of Construction Engineering and Management, 144(3), p. 04017121.

Chong, H. Y., \& Low, T. S. (2014). Accidents in Malaysian construction industry: statistical data and court cases. International Journal of Occupational Safety and Ergonomics, 20(3), pp. 503-513.

Economics, Trading. (2018). Bangladesh GDP From Construction. Retrieved 05 January, 2019, from https://tradingeconomics. com/bangladesh/gdp-from-construction

Endroyo, B., Yuwono, B. E., \& Mardapi, D. (2015). Model of learning/ training of occupational safety \& health $(\mathrm{OSH})$ based on industry in the construction industry. Procedia Engineering, 125, pp. 83-88.

Enshassi, A., Mohamed, S., \& Abushaban, S. (2009). Factors affecting the performance of construction projects in the Gaza strip. Journal of Civil engineering and Management, 15(3), pp. 269-280.

Fang, D., Wu, C., \& Wu, H. (2015). Impact of the supervisor on worker safety behavior in construction projects. Journal of Management in Engineering, 31(6), p. 04015001.

Forbes, L. H., \& Ahmed, S. M. (2010). Modern Construction: Lean Project Delivery and Integrated Practices. CRC press, Boca Raton.

Gambatese, JA. (2000). Owner involvement in construction site safety. Paper presented at the Construction Congress VI: Building Together for a Better Tomorrow in an Increasingly Complex World.

Gambatese, J. A. (1998). Liability in designing for construction worker safety. Journal of Architectural Engineering, 4(3), pp. 107-112.

George, D., \& Mallery, P. (2016). IBM SPSS Statistics 23 step by step: A simple guide and reference. Routledge, Abingdon.

Gunduz, M., Birgonul, M. T., \& Ozdemir, M. (2016). Fuzzy structural equation model to assess construction site safety performance. Journal of Construction Engineering and Management, 143(4), p. 04016112.

Hamid, A. R. A., Majid, Md Z. A., \& Singh, B. (2008). Causes of accidents at construction sites. Malaysian Journal of Civil Engineering, 20(2), pp. 242-259.

Hamid, ARA, Singh, B, \& Arzmi, AB. (2014). Construction Project Manager Ways to Cope with Stress at Workplace. Paper presented at the SEPKA 2014: National Seminar on Civil Engineering Research, Training Center, UTM Skudai. FKA-PGSS FKA-UTM.

Haslam, R. A., Hide, S. A., \& Gibb, A. G. F. (2005). Contributing factors in construction accidents. Applied Ergonomics, 36(4), pp. 401-415. doi: 10.1016/j.apergo.2004.12.002.

Hiyassat, M. A., Hiyari, M. A., \& Sweis, G. J. (2016). Factors affecting construction labour productivity: a case study of Jordan.
International Journal of Construction Management, 16(2), pp. 138-149.

Hongling, G., Yantao, Y., Weisheng, Z., \& Yan, L. (2016). BIM and safety rules based automated identification of unsafe design factors in construction. Procedia Engineering, 164, pp. 467-472.

Hossain, M. M., \& Ahmed, S. (2018). A case study on safety assessment of construction project in Bangladesh. Journal of Construction Engineering, Management \& Innovation, 1(4), pp. 147-156.

Huang, X., \& Hinze, J. (2006). Owner's role in construction safety. Journal of Construction Engineering and Management, 132(2), pp. 164-173.

Islam, M. H., Morshed, S. Y., \& Karim, M. R. (2015). Construction Safety Practice in Bangladesh: A Case Study in KUET, Mirerdanga and Teliganti Union. Paper presented at the International Conference on Recent Innovation in Civil Engineering for Sustainable Development, Department of Civil Engineering, DUET - Gazipur, Bangladesh.

Islam, M. S., Razwanul, I., \& Mahmud, Md T. (2017). Safety practices and causes of fatality in building construction projects: a Case Study for Bangladesh. Jordan Journal of Civil Engineering, 11(2).

Jadhav, P., Desai, D., \& Gupta, A. (2016). Analysis of construction cost overrun causes-contractor's view. Imperial Journal of Interdisciplinary Research, 2(8).

Jannadi, O. A., \& Bu-Khamsin, M. S. (2002). Safety factors considered by industrial contractors in Saudi Arabia. Building and Environment, 37(5), pp. 539-547.

Karakhan, A., Xu, Y., Nnaji, C., \& Alsaffar, O. (2019). Technology Alternatives for Workplace Safety Risk Mitigation in Construction: Exploratory Study. Advances in Informatics and Computing in Civil and Construction Engineering. Springer, Berlin, pp. 823-829.

Kartam, N. A., \& Bouz, R. G. (1998). Fatalities and injuries in the Kuwaiti construction industry. Accident Analysis \& Prevention, 30(6), pp. 805-814.

Kheni, N. A., Dainty, A. R., \& Gibb, A. (2008). Health and safety management in developing countries: a study of construction SMEs in Ghana. Construction Management and Economics, 26(11), pp. 1159-1169.

Larsen, J. K., Shen, G. Q., Lindhard, S. M., \& Brunoe, T. D. (2015). Factors affecting schedule delay, cost overrun, and quality level in public construction projects. Journal of Management in Engineering, 32(1), p. 04015032.

Le-Hoai, L., Lee, Y. D., \& Lee, J. Y. (2008). Delay and cost overruns in Vietnam large construction projects: A comparison with other selected countries. KSCE Journal of Civil Engineering, 12(6), pp. 367-377.

Leung, M.-Y., Liang, Q., \& Olomolaiye, P. (2015). Impact of job stressors and stress on the safety behavior and accidents of construction workers. Journal of Management in Engineering, 32(1), p. 04015019.

Li, X., Yi, W., Chi, H.-L., Wang, X., \& Chan, A. P. C. (2018). A critical review of virtual and augmented reality (VR/AR) applications in construction safety. Automation in Construction, 86, pp. 150-162.

Lundgren, R. E., \& McMakin, A. H. (2018). Risk communication: A handbook for communicating environmental, safety, and health risks. John Wiley \& Sons, Hoboken.

Ogwueleka, A. C. (2013a). A review of safety and quality issues in the construction industry. Journal of Construction Engineering and Project Management, 3(3), pp. 42-48. 
Ogwueleka, A. C. (2013b). A review of safety and quality issues in the construction industry. KICEM Journal of Construction Engineering and Project Management, 3(3), pp. 42-48. doi: 10.6106/JCEPM.2013.3.3.042.

Pallant, J. (2016). SPSS Survival Manual: A Step by Step Guide to Data Analysis Using IBM Spss (6. utg.): Maidenhead. Open University Press.

Priyadarshani, K., Gayani, K., \& Sajani, J. (2013). Construction safety assessment framework for developing countries: a case study of Sri Lanka. Journal of Construction in Developing Countries, 18(1), pp. 33-51.

Priyadarshani, K., Karunasena, G., \& Jayasuriya, S. (2013). Construction safety assessment framework for developing countries: a case study of Sri Lanka. Journal of Construction in Developing Countries, 18(1), p. 33.

Raheem, A. A., \& Issa, R. R. A. (2016). Safety implementation framework for Pakistani construction industry. Safety Science, 82, pp. 301-314.

Reason, J. (2016). Managing the risks of organizational accidents. Routledge, Abingdon.

Report, Star Online. (2017). 1,242 killed in workplace accidents in 2017, The Daily Star.

Rumane, A. R. (2016). Quality management in construction projects. CRC Press, Boca Raton.

Sanchez, F. A. S., Pelaez, G. I. C., \& Alis, J. C. (2017). Occupational safety and health in construction: a review of applications and trends. Industrial Health, 55(3), pp. 210-218.

Shehu, Z., Endut, I. R., Akintoye, A., \& Holt, G. D. (2014). Cost overrun in the Malaysian construction industry projects: A deeper insight. International Journal of Project Management, 32(8), pp. 1471-1480.

Shibani, A., Saidani, M., \& Alhajeri, M. (2013). Health and safety influence on the construction project performance in United Arab Emirates (UAE). Journal of Civil Engineering and Construction Technology, 4(2), pp. 32-44.

Shin, M., Lee, H.-S., Park, M., Moon, M., \& Han, S. (2014). A system dynamics approach for modeling construction workers' safety attitudes and behaviors. Accident Analysis \& Prevention, 68, pp. 95-105.

Sousa, V., Almeida, N. M., \& Dias, L. A. (2014). Risk-based management of occupational safety and health in the construction industry-Part 1: Background knowledge. Safety Science, 66, pp. 75-86.

Star, Daily. (2017). Ensuring construction safety in Bangladesh, The Daily Star. Retrieved from https://www.thedailystar. net/round-tables/ensuring-construction-safety-bangladesh-1475314

Sveikauskas, L., Rowe, S., Mildenberger, J., Price, J., \& Young, A. (2016). Productivity growth in construction. Journal of Construction Engineering and Management, 142(10), p. 04016045.

Swuste, P., Frijters, A., \& Guldenmund, F. (2012). Is it possible to influence safety in the building sector?: A literature review extending from 1980 until the present. Safety Science, 50(5), pp. 1333-1343.

Tam, C. M., Zeng, S. X., \& Deng, Z. M. (2004). Identifying elements of poor construction safety management in China. Safety Science, 42(7), pp. 569-586.

Teo, E. A. L., \& Ling, F. Y. Y. (2006). Developing a model to measure the effectiveness of safety management systems of construction sites. Building and Environment, 41(11), pp. 1584-1592.

Toole, T. M. (2005). Increasing engineers' role in construction safety: opportunities and barriers. Journal of Professional Issues in Engineering Education and Practice, 131(3), pp. 199-207.

Udo, U. E., Usip, E. E., \& Asuquo, C. F. (2016). Effect of lack of adequate attention to safety measures on construction sites in Akwa Ibom State, Nigeria. Journal of Earth Sciences and Geotechnical Engineering, 6(1), pp. 113-121.

Unnikrishnan, S., Iqbal, R., Singh, A., \& Nimkar, I. M. (2015). Safety management practices in small and medium enterprises in India. Safety and Health At Work, 6(1), pp. 46-55.

Williams, O. S., Hamid, R. A., \& Misnan, M. S. (2019). Causes of building construction related accident in the south-western states of Nigeria. International Journal of Built Environment and Sustainability, 6(1), pp. 14-22.

Winge, S., \& Albrechtsen, E. (2018). Accident types and barrier failures in the construction industry. Safety Science, 105, pp. 158-166.

Wu, C., Fang, D., \& Li, N. (2015). Roles of owners' leadership in construction safety: the case of high-speed railway construction projects in China. International Journal of Project Management, 33(8), pp. 1665-1679.

Yiu, N. S. N., Sze, N. N., \& Chan, D. W. M. (2018). Implementation of safety management systems in Hong Kong construction industry-a safety practitioner's perspective. Journal of Safety Research, 64, pp. 1-9.

Yu, Q. Z., Ding, L. Y., Zhou, C., \& Luo, H. B. (2014). Analysis of factors influencing safety management for metro construction in China. Accident Analysis \& Prevention, 68, pp. 131-138.

Zeng, S. X., Tam, C. M., \& Tam, V. W. Y. (2015). Integrating safety, environmental and quality risks for project management using a FMEA method. Engineering Economics, 66(1).

Zhou, Z., Goh, Y. M., \& Li, Q. (2015). Overview and analysis of safety management studies in the construction industry. Safety Science, 72, pp. 337-350. 